\title{
Skrining Dan Seleksi Bakteri Simbion Spons Penghasil Enzim Ekstraseluler Sebagai Agen Bioremediasi Bahan Organik Dan Biokontrol Vibriosis Pada Budidaya Udang
}

\author{
Wilis Ari Setyat*, Ahmad Saddam Habibi, Subagiyo, Ali Ridlo, Ninwani S., Rini Pramesti \\ Departement IImu Kelautan, Fa kultas Perikanan dan IImu Kelautan, Universita s Diponeg oro \\ JI. Prof. Soedarto, SH. Kampus UNDIP Tembalang, Semarang 50275 \\ E-mail: wilisarisetyati@yahoo.co.id
}

\begin{abstract}
Abstrak
Pesatnya kegiatan budidaya perikanan dengan penerapan sistem intensif dalam beberapa tahun terakhir, telah memunculkan permasalahan berupa penurunan daya dukung tambak bagi kehidupan organisme budidaya. Dampak lanjut yang ditimbulkan adalah tejadinya serangkaian penyakit dan kerusakan kondisi lingkungan. Langkah antisipatif melalui penerapan bioremediasi merupakan solusi untuk mencegah kerusakan yang lebih serius. Dalam proses bioremediasi, enzim memainkan peran katalis yang mempercepat reaksi biokimia di kolam tanah dan a ir. Bakteri yang berasosiasi dengan spons memiliki beragam senyawa bioaktif yang dapat menghambat pertumbuhan bakteri patogen. Tujuan dari penelitian ini adalah isolasi dan skrining bakteri yang berasosiasi dengan spons yang memiliki a ktivitas enzim ekstra seluler (proteolitik, a milolitik, selulolitik, dan lipolitik) dan aktivitas antibakteri, serta mengetahui interaksi sifat antagonisme antar isolat terbaik, dan identifikasi spesies bakteri secara fenotipik. Penelitian ini dilakukan dalam 4 tahap: koleksi sampel, isolasi, seleksi, dan identifikasi. Hasil penelitian menunjukkan bahwa total bakteri simbion spons yang diperoleh 15 isolat dengan potensi 15 isolat proteolitik, 12 isolat amilolitik, 12 isolat lipolitik, dan 4 isolat selulolitik. Terdapat 10 isolat memiliki a ktivitas antibakteri terhadap Vibrio harveyi dan 2 isolat memiliki a ktivitas antibakteri terhadap Vibrio alginolytic us. Isolat bakteri terbaik SP.1.3, SP.5.1, dan SP.5.3 tidak memiliki aktivitas saling antagonis antar ketiganya. Identifikasi fenotipik dari 3 isolat diduga bahwa isolat SP.1.3, SP.5.1, dan SP.5.2 diidentifika si sebagai Ba cillus sp., Ac ineto ba cter sp., dan Pseudomonas sp.
\end{abstract}

Kata kunci: Bakteri simbion spons, enzim ekstraseluler, bioremediasi, vibriosis

\begin{abstract}
The rapid growing up aquaculture activities with implementation of an intensive system in recent years has given rise to a decrease in the camying capacity of the pond for cultivation of living organisms. Further impacts a re caused by a series of disease and damage to the environment. Antic ipatory measures through a pplic ation of bioremediation is a solution to prevent more serious damage. In the process of bioremediation, enzymes play a role of catalysts that raise up biochemical reactions in soil and water pools. Bacteria associated with sponge has a variety of bioactive compounds that can inhibit the growth of pathogenic bacteria. The aim of this study was the isolation and screening of bacteria associated with sponge having extracellular enzymes activity and antibacterial activity, and to know antagonism interaction, and identification of bacterial phenotypically. This research was camied out in 4 stages: sample collection, isolation, selection, and identification. The results showed that sucessfully obtained 15 isolates sponge-associated bacteria potentially 15 isola tes proteolytic, 12 isolates a mylolytic, 12 isola tes lipolytic, and 4 isola tes cellulolytic. There were succesfully obtained 10 isolates have antibacterial activity aga inst Vibrio harveyi and 2 isolates have antibacterial a ctivity a ga inst Vibrio a lginolytic us. The best isolates SP.1.3, SP.5.1, and SP.5.2 not have mutually antagonistic activity between them. Based on phenotypic
\end{abstract}


identific ation, three isolates showed that isolates SP.1.3, SP.5.1, and SP.5.2 identified as Bacillus sp., Ac inetobacter sp., and Pseudomonas sp.

Keywords: sponge assoc ia ted bacteria, extracellula r enzymes, bioremediation, vibriosis.

\section{PENDAHULUAN}

Akuakultur saat ini dianggap sebagai salah satu industri yang paling cepat berkembang dan memberikan kontribusi signifikan terhadap perokonomian dunia. Salah satu komoditas sektor perikanan yang bemila i ekonomi tinggi ialah udang, dengan pangsa pasar di manca negara yang luas dan terus meningkat. Kecenderungan yang terjadi dalam budidaya tambak udang, khususnya yang menerapkan teknologi semi intensif dan intensif adalah memburuknya keadaan lingkungan tambak sejalan dengan berlangsungnya masa pemeliharaan (Gamo, 2004; Maulina et al., 2012).

Keberadaan bahan organik yang tinggi berpengaruh besar terhadap karakteristik kimia tanah dan air lingkungan tambak. Kandungan bahan organik yang tinggi akan menyebabkan peningkatan konsumsi oksigen untuk proses biodekomposisi. Hal ini menyebabkan penurunan kadar oksigen terlarut yang berdampak secara langsung pada udang dan terbentuknya produk perombakan bahan organik secara anaerob yang bersifat toksik bagi udang (Avnimelech dan Ritvo, 2003).

Kualitas lingkungan yang buruk menyebabkan penurunan ketahanan tubuh organisme terhadap serangan penyakit (Kilawati dan Maimunah, 2014). Pada saat kondisi udang lemah dan faktor lingkungan udang yang buruk bakteri Vibrio akan menginfeksi dan menyebabkan penyakit. Penyakit Vibriosis menupakan penyakit utama pada benih yang dapat menimbulkan kematian sampai $100 \%$ dalam waktu 2 minggu (Felix et al., 2011).

Pada prinsipnya penyakit yang menyerang udang budidaya melalui proses hubungan antara tiga faktor yaitu kondisi lingkungan (kualitas air), kondisi inang (udang), dan adanya jasad patogen (penyakit) (Kilawati dan Maimunah, 2014). Salah satu upaya altematif yang terus dikembangkan ialah teknik bioremediasi, merupakan pendekatan biologis dalam pengelolaan kualitas air tambak (Badjoeri dan Widiyanto, 2008) dengan memanfaatkan aktivitas enzimatik bakteri dalam merombak bahan organic.

Santos (2014) menyatakan, enzim ekstraseluler seperti protease, amilase, selulase dan lipase memainkan peran penting dalam bioremediasi untuk budidaya, terutama dalam produksi intensif. Menurut Feby and Nair (2014), bakteri yang berasosiasi dengan spons merupakan sumber enzim hidrolitik ekstraseluler yang sangat baik karena permukaan dan ruang intemal spons lebih kaya nutrisi. Selain itu, diketahui bahwa bakteri yang berasosiasi dengan spons mampu menghasilkan metabolit sekunder bagi inangnya yang berfungsi sebagai pertahanan kimia terhadap predator (J uneius and Selvin, 2012), untuk komunikasi dan perlindungan terhadap infeksi (Radjasa et al., 2007).

Permasalahan yang terjadi pada kegiatan akuakultur cukup kompleks. Sehingga diperlukan agen konsorsium bioremediator bahan organik yang ma mpu menjaga stabilita slingkungan dan juga memiliki kemampuan dalam menekan munculnya bakteri patogen. Pendekatan secara mikrobiologi digunakan dalam studi ini untuk memberikan gambaran yang menyeluruh akan tingkat potensi, keanekaragaman dan karakteristik fenotip bakteri yang berasosiasi dengan spons.

\section{MATERI DAN METODE}

Pengambilan sampel ini dilakukan secara purposif, yaitu dengan menyusuri dasar laut. Pengambilan sampel spons 
dilakukan dengan skin diving di Pantai Ujung Pining, Jepara pada kedalaman sekitar 1-2 m. Spons diambil dengan dipotong menggunakan pisau kemudian dimasukkan dalam botol sampel. Spons kemudian dicuci dengan a ir laut steril dan dimasukkan ke dalam botol sampel plastik yang telah diisi dengan air laut, kemudian disimpan dalam cool box berisi es batu untuk dianalisis selanjutnya di la bora torium.

\section{Penanaman Bakteri Simbion Spons}

Sampel spons digerus dengan menggunakan mortar secara aseptis. Setelah hancur diambil 1 gram spons, dimasukkan ke dalam tabung reaksi yang berisi $9 \mathrm{ml}$ air laut steril $\left(10^{\circ}\right)$, kemudian digojog hingga homogen. Selanjutnya dari pengenceran $10^{\circ}$ diambil $1 \mathrm{ml}$ dengan mikropipet kemudian dimasukkan ke dalam $9 \mathrm{ml}$ air laut steril dan diperoleh pengenceran $10^{-1}$. Pengenceran dilanjutkan hingga diperoleh pengenceran 10-5. Pada $^{-5}$ masing-masing pengenceran diambil sebanyak $100 \mu \mathrm{l}$ suspensi bakteri menggunakan mikropipet dan diinokulasikan ke dalam cawan petri yang telah diisi media Zobell laut agar. Selanjutnya diratakan menggunakan spreader dan diinkubasikan selama $2 \times 24$ jam pada suhu $37^{\circ} \mathrm{C}$ (Anand et al., 2006).

\section{Isolasi dan Purifikasi Bakteri Simbion Spons}

Koloni-koloni bakteri yang tumbuh diamati morfologi dan wama koloninya yang mengacu pada Cappucino and Sheman (1999). Setiap kenampakkan morfologi dan wama yang berbeda pada tiap cawan petri diambil. Kemudian dilakukan metode streak untuk pemisahan dan pemumian tiap-tiap bakteri pada pemukaan media Zobell. cawan petri tersebut diinkubasikan selama $2 \times 24$ jam dan diamati pertumbuhannya. Apabila belum diperoleh kultur mumi, maka dilakukan pemisahan kembali dengan metode streak hingga diperoleh kultur mumi (Setyati dan Subagiyo, 2012). Setelah didapatkan kultur mumi kemudian kultur bakteri disimpan pada tabung reaksi yang berisi media agar mining Zobell dengan metode streak. Hasil isolasi pada media Zobell agar mining kemudian diinkubasi selama 24 jam dalam inkubator.

\section{Seleksi Bakteni Enzimatik}

Tiap isolat mumi pada media mining diambil menggunakan ose kemudian diinokulasikan ke dalam $5 \mathrm{ml}$ media Zobell laut cair pada tabung reaksi yang berbeda. Isolat diinkubasi diatas shaker pada suhu ruang selama 24 jam.

Uji a ktivitas produksi enzim protease dilakukan dengan prosedur menurut Setyati dan Subagiyo (2012). Media uji yang digunakan adalah media Zobell agar yang telah diperkaya skim milk (1\%). Paper disc steril diletakkan diatas skim milk agar. Tiap kultur cair diinokulasikan ke paper disc. Selanjutnya diinkubasi pada suhu kamar selama 24 jam. Identifikasi aktivitas proteolitik dilakukan dengan mengukur zona bening yang terbentuk disekitar pa per disc.

Uji aktivitas produksi amilase dilakukan dengan prosedur menurut Setyati dan Subagiyo (2012). Media uji yang digunakan adalah media Zobell laut agar yang telah diperkaya soluble starch (1\%). Paper disc steril diletakkan diatas skim milk agar. Tiap kultur cair diinokulasikan ke paper disc. Selanjutnya diinkubasi pada suhu kamar selama 24 jam. Identifikasi aktivitas amilolitik dilakukan dengan menuang larutan Gram iodin ke atas media kultur. Zona bening yang terbentuk disekitar paper disc diukur.

Uji aktivitas produksi selulase dilakukan dengan prosedur menurut Kasana et al (2008). Media uji yang digunakan adalah media Zobell laut agar yang telah diperkaya CMC (1\%). Paper disc steril diletakkan diatas media uji. Tiap kultur cair diinokulasikan ke paper disc. Selanjutnya diinkubasi pada suhu kamar selama 48 jam. Identifikasi aktivitas selulolitik dilakukan dengan menuang larutan Gram iodin ke atas media kultur. Zona bening yang terbentuk disekitar paperdisc diukur.

Uji a ktivitas produksi lipase dilakukan dengan prosedur menurut Setyati dan Subagiyo (2012). Media uji yang digunakan adalah media Zobell laut agar yang telah diperkaya Tween (1\%). Paper disc steril diletakkan diatas media uji. Tiap 
kultur cair diinokulasikan ke paper disc. Selanjutnya diinkubasi pada suhu kamar selama 24 jam. Setelah inkubasi, aktivitas lipolitik ditunjukkan oleh zona putih keruh yang terbentuk disekitar paper disc .

\section{Ufi Antibakteri}

Uji aktivitas antibakteri dilakukan dengan metode disk difusi antara bakteri simbion dengan bakteri patogen (Radjasa et al, 2007). Masing-masing bakteri V. harveyi, V. alginolytic us, dan bakteri simbion spons hasil isolasi dikultur dalam media Zobell laut cair selama 24 jam. Sebanyak $100 \mu \mathrm{l}$ bakteri V. harveyi dan V. alginolyticus yang sudah dikultur diinokulasikan ke media Zobell laut agar. Kemudian dihomogenkan dan dituang ke dalam cawan petri secara aseptis. Paper disc steril ukuran $8 \mathrm{~mm}$ diletakkan di atas media Zobell laut agar yang telah terdapat bakteri patogen Vibrio. Hasil kultur dari tiap isolat diambil sebanyak 40 $\mu l$ dan dipipetkan ke dalam paper disc. Selanjutnya diinkubasi selama 24 jam dalam inkubator. Terbentuknya zona bening disekitar paper disc mengindikasikan adanya aktivitas antiba kteri. Besamya aktivitas antibakteri diukur menggunakan jangka sorong.

\section{Ufi Antagonis Antar Isolat}

Uji antagonis yang dilakukan menggunakan metode Cross streak pada media Zobell laut agar (Saha and Santra, 2014). Lima isolat terbaik dipilih berdasarkan aktivitas enzim dan aktivitas antibakterinya. Isolat yang terpilih distreak berupa garis lunus vertikal pada media Zobell laut agar dan isolat terpilih la innya distreak melintang dikedua sisinya. Selanjutnya diinkubasi selama 24 jam pada suhu $37^{\circ} \mathrm{C}$. Pengujian dilakukan untuk masing-masing isolat. Variabel yang diamati adalah ada atau tidaknya zona hambat yang terbentuk pada isolat.

\section{HASILDAN PEMBAHASAN}

Hasil isolasi dan seleksi bakteri simbion spons yang mempunyai kemampuan menghasilkan enzim proteolitik (protease), a milolitik (a mila se), selulolitik (selulase), dan lipolitik (lipase) yang berasal dari Pantai Ujung Piring Jepara ditunjukkan pada Gambar 1 dan Tabel 1.

Lima belas isolat bakteri yang diuji didapatkan 15 isolat memiliki aktivitas proteolitik, 12 isolat memiliki aktivitas amilo litik, 4 isolat memiliki a ktivitas selulolitik, dan 12 isolat memiliki aktivitas lipolitik. Isolat yang memiliki aktivitas proteolitik, a milolitik, selulolitik, dan lipolitik sebanyak 3 isolat. Enzim ini dapat menghidrolisis senyawa kompleks seperti protein, lemak dan karbohidrat dari alga atau mikroorganisme yang tertelan atau tersaring oleh spons menjadi senyawa mikromolekul yang bemutrisi (Anand et al., 2006).

Lima belas isolat bakteri simbion spons yang diperoleh menunjukkan aktivitas proteolitik. Shanmughapriya et al., (2008) pada penelitiannya melaporkan bahwa aktivitas protease adalah yang paling tinggi dari bakteri simbion spons Fasciospongia cavemosa yang diambil dari semenanjung pantai timur India. Bakteri yang mampu mensekresikan enzim protease memiliki kemampuan menghidrolisis senyawasenyawa bersifat protein menjadi oligopeptida, peptida rantai pendek, dan asa m a mino (Setyati dan Subagyo, 2012).

Isolat yang menunjukkan aktivitas amilolitik sebanyak 12 isolat. Amilase bisa menghidrolisis gula kompleks seperti pati menjadi gula sederhana seperti glukosa, maltosa dan dekstrin. Tiga isolat bakter simbion spons yang diperoleh menunjukkan aktivitas selulolitik. Bakteri yang memiliki aktivitas selulolitik memiliki kemampuan untuk menghasilkan enzim selulase yang disekresikan ke lingkungannya. Enzim selulolitik ekstraseluler ini bekerja menghidrolisis selulosa menjadi polisakarida yang lebih sederhana yang disebut cellodextrin (Zhang dan Kim, 2010).

Terdapat 12 isolat bakteri yang memiliki aktivitas hidrolitik terhadap lipid yang ditunjukkan dengan terbentuknya endapan asam lemak. Isolat bakteri ini memiliki kemampuan enzim lipase ekstraseluler. Enzim ini bekerja mengkatalis pemecahan lemak dan minyak yang selanjutnya dilepas menjadi asam lemak 


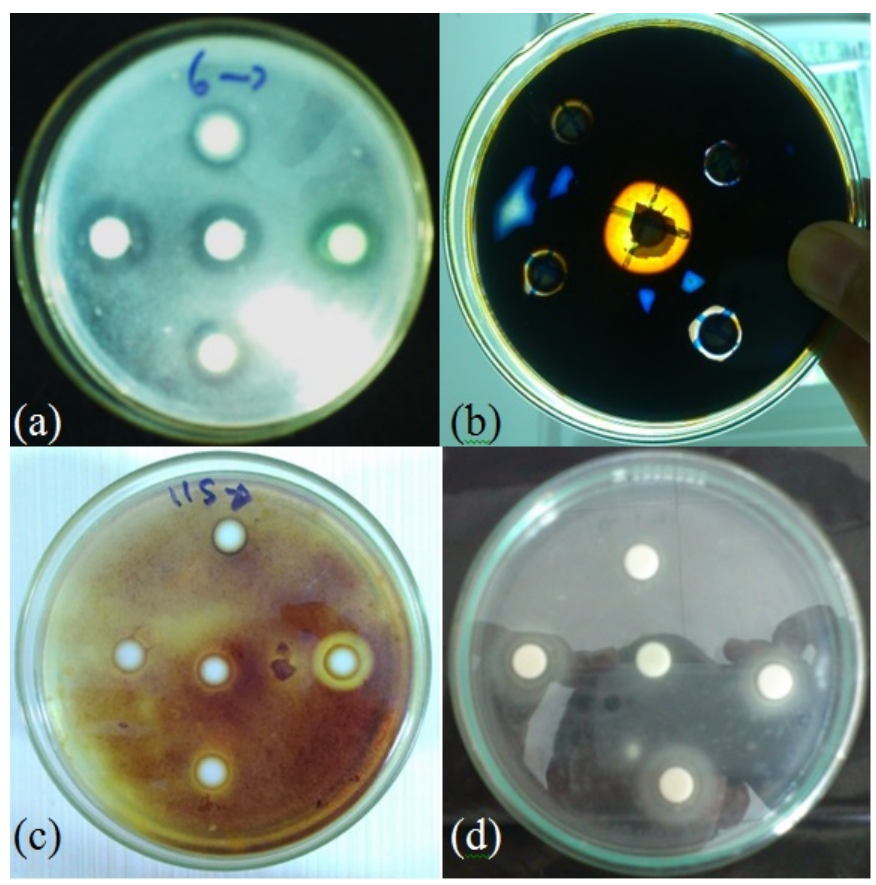

Gambar 1. Hasil pengujian a ktivitas enzimatik (a) proteolitik, (b) a milolitik,(c) selulolitik, (d) lipolitik.

Tabel 1. Hasil Seleksi Bakteri Simbion Spons berdasarkan kemampuan proteolitik, amilolitik, selulolitik, dan lipolitik.

\begin{tabular}{|c|c|c|c|c|c|}
\hline \multirow{2}{*}{ Pengenceran } & \multirow{2}{*}{ Kode Isolat } & \multicolumn{4}{|c|}{ Dia meter Zona Hidrolitik (mm) } \\
\hline & & Protease & Amilase & Selulase & Lipase \\
\hline \multirow{4}{*}{$10^{-1}$} & SP.1.1 & $14,20 \pm 0,28$ & $8,30 \pm 0,28$ & $11,25 \pm 0,07$ & 0 \\
\hline & SP.1.2 & $14,05 \pm 0,21$ & $10,40 \pm 0,18$ & 0 & $15,90 \pm 0,14$ \\
\hline & SP.1.3 & $16,10 \pm 0,14$ & $13,60 \pm 0,18$ & 0 & $13,55 \pm 0,35$ \\
\hline & SP.1.4 & $13,25 \pm 0,35$ & $12,15 \pm 0,21$ & $12,20 \pm 0,28$ & $13,05 \pm 0,07$ \\
\hline \multirow{5}{*}{$10^{-2}$} & SP.2.1 & $15,20 \pm 0,14$ & $20,10 \pm 0,14$ & 0 & $17,05 \pm 0,21$ \\
\hline & SP.2.2 & $15,05 \pm 0,07$ & $15,60 \pm 0,28$ & 0 & $16,00 \pm 0,28$ \\
\hline & SP.2.3 & $16,15 \pm 0,21$ & 0 & 0 & $17,35 \pm 0,21$ \\
\hline & SP. 2.4 & $15,90 \pm 0,14$ & 0 & 0 & $11,60 \pm 0,28$ \\
\hline & SP.2.5 & $18,20 \pm 0,14$ & 0 & 0 & 0 \\
\hline $10^{-3}$ & SP.3.1 & $17,30 \pm 0,28$ & $13,00 \pm 0,28$ & $16,50 \pm 0,42$ & $14,20 \pm 0,28$ \\
\hline \multirow{2}{*}{$10^{-4}$} & SP.4.1 & $12,15 \pm 0,21$ & $15,00 \pm 0,14$ & 0 & 0 \\
\hline & SP.4.2 & $14,00 \pm 0,28$ & $11,20 \pm 0,14$ & $13,90 \pm 0,28$ & $11,80 \pm 0,28$ \\
\hline \multirow{3}{*}{$10^{-5}$} & SP.5.1 & $18,95 \pm 0,35$ & $20,50 \pm 0,42$ & 0 & $16,25 \pm 0,21$ \\
\hline & SP.5.2 & $15,20 \pm 0,28$ & $14,20 \pm 0,14$ & 0 & $16,00 \pm 0,28$ \\
\hline & SP.5.3 & $16,80 \pm 0,42$ & $20,10 \pm 0,14$ & 0 & $13,15 \pm 0,21$ \\
\hline
\end{tabular}

bebas, diacygliserol, monogliserol dan gliserol (Zhang and Kim, 2010).

Hasil penelitian Feby and Nair, (2010), menjelaskan bahwa bakteri yang berasosiasi dengan spons merupakan sumber yang sangat baik untuk enzim ekstraseluler seperti amilase, protease, gelatinase, lipase, deoksiribonuklease, dan fosfatase. Tingginya keanekaragaman 
bakteri heterotrofik yang berasosiasi dengan spons memproduksi enzim ekstra seluler yang bertanggung jawab dalam degradasi biopolimer.

Budidaya perikanan merupakan kegiatan yang menghasilkan sejumlah besar limbah, terdiri dari metabolisme oleh produk, sisa pakan, materi feses, dan limbah produk selama moulting yang mengarah pada penurunan kualitas a ir dan wabah penyakit (Antony and Philip, 2006). Dalam proses bioremediasi, enzim memainkan peran katalis yang mempercepat reaksi biokimia di kolam tanah dan a ir. Ketika ditambahkan ke dalam air kolam atau disebar di atas kolam tanah, enzim mampu mendegradasi konstituen organik. Enzim juga secara alami diproduksi dan dikeluarkan oleh beberapa mikroba. Enzim ekstraseluler, seperti selula se, protease dan amilase, diproduksi selama fermentasi aerobik bahan organik oleh mikroorganisme (Santos, 2014).

Tabel 2. menunjukkan isolat SP.2.3 dapat menghambat kedua bakteri patogen dengan besar zona hambat sebesar 17,80 $\pm 0,56 \mathrm{~mm}$ terhadap Vibrio harveyi dan 14,03 $\pm 0,38 \mathrm{~mm}$ terhadap $\mathrm{V}$. alginolyticus. Isolat yang mampu menghambat $V$. alginolytic us sebanyak 2 isolat. Isolat yang mampu menghambat $\mathrm{V}$. harveyi sebanyak 10 isolat. Tiga isolat aktivitas antibakteri tertinggi pada isolat SP.1.2, SP.1.3, dan SP.2.3. Pengukuran diameter zona hambat pada isolat-isolat yang memiliki aktivitas antibakteri diperoleh kisaran diameter 13,23 - 19,90 $\mathrm{mm}$.

Perbedaan kemampuan daya hambat pada setiap isolat disebabkan oleh perbedaan kandungan metabolit sekunder yang dimiliki oleh masing masing isolat yang telah berdifusi terlebih dahulu ke dalam agar, sehingga pertumbuhan bakteri patogen menjadi terhambat. Menurut Cappuccino and Sherman (1999), beberapa faktor yang mempengaruhi terbentuknya zona hambat tergantung kepada difusi bahan antimikroba ke dalam media dan interaksinya dengan mikroorga nisme uji, jumlah mikroorganisme yang digunakan, kecepatan tumbuh mikroorganisme yang diuji dan sensitifitas mikroorganisme terhadap bahan antimikroba yang diuji.

Tábel 2. Aktivitas Antibakteri 15 Isolat Bakteri Simbion Spons.

\begin{tabular}{ccc}
\hline \multirow{2}{*}{$\begin{array}{c}\text { Kode } \\
\text { Isolat }\end{array}$} & \multicolumn{2}{c}{ Diameter Zona Hambat $(\mathrm{mm})$} \\
\cline { 2 - 3 } & V. harveyi & V. alginolytic us \\
\hline SP.1.1 & $15,30 \pm 0,44$ & 0 \\
SP.1.2 & $19,90 \pm 0,26$ & 0 \\
SP.1.3 & $17,80 \pm 0,50$ & 0 \\
SP.1.4 & 0 & 0 \\
SP.2.1 & 0 & 0 \\
SP.2.2 & 0 & $10,20 \pm 0,17$ \\
SP.2.3 & $17,77 \pm 0,56$ & $14,03 \pm 0,38$ \\
SP.2.4 & $13,27 \pm 0,25$ & 0 \\
SP.2.5 & 0 & 0 \\
SP.3.1 & 0 & 0 \\
SP.4.1 & $13,23 \pm 0,21$ & 0 \\
SP.4.2 & $14,00 \pm 0,46$ & 0 \\
SP.5.2 & $16,43 \pm 0,15$ & 0 \\
SP.5.3 & $13.27 \pm 0,55$ & 0 \\
\hline
\end{tabular}

Metode cross streak dilakukan untuk menentukan antagonisme diantara isolat bakteri yang bertujuan untuk mengembangkan aplikasi konsorsium dalam berbagai aspek. Hasil uji antagonis dapat dilihat pada Gambar 2 dan Tabel 3. isolat SP.2.3 terhadap isolat SP.3.1 menunjukkan interaksi antagonis, sehingga tidak mungkin kembangkan konsorsium menggunakan gabungan kedua isolat tersebut. Adanya interaksi antagonis menunjukkan bahwa mereka bersifat saling mengalahkan. Hal ini bemakna bahwa antar isolat terjadi kompetisi nutrisi ata upun terbentuk zat antibakteri dan tidak dapat hidup bekerja sama. Isolat bakteri dapat bersifat antagonis satu sama lain disebabkan oleh beberapa faktor seperti kompetisi nutrisi, pembentukan zat antibakter dan lain - lain. Zulaikhah (2005) menyatakan bahwa faktor - faktor tersebut adalah penggunaan nutrisi, perubahan nilai $\mathrm{pH}$, perubahan potensial redoks, pembentukan zat antimikroba dan bakteriofag. 


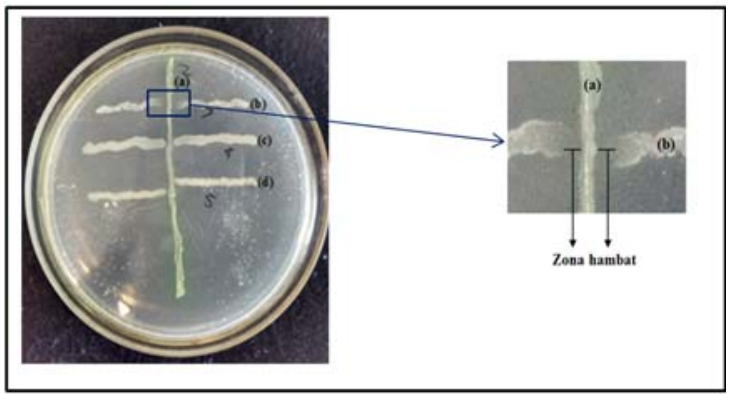

Gambar 2. Hasil uji antagonis (a) isolat SP.2.3 (b) isolat SP.3.1 (c) isolat SP.5.1 (d) isolat SP.5.2.

Isolat bakteri SP.1.3, SP.5.1, dan SP.5.3 tidak memiliki aktivitas saling antagonis antar ketiganya. Isolat-isolat tersebut dapat dikembangkan sebagai konsorsium bakteri. Hubungan a ntar ba kteri korsorsium dalam keadaan substrat yang mencukupi tidak akan saling mengganggu, tetapi saling bersinergi sehingga menghasilkan efisiensi perombakan yang lebih tinggi selama proses pengolahan. Interaksi sinergisme antara konsorsium bakteri yang digunakan atau interaksinya dengan lingkungan menyebabkan terjadinya proses degradasi bahan cemaran organik di da lam limbah (Prakash et al., 2003).

Karakterisasi isolat bakteri terbaik (SP.1.3, SP.5.1, dan SP.5.3) dilakukan berdasarkan hasil pengamatan makroskopik dan uji aktivitas biokimia, pada Tabel 4, kemudian dicocokkan dengan Cowan and Steel's Manual for the Identification of Medical Bacteria dan Bergey's Manual of Determinative Bacteriology untuk mengetahui genus dan spesiesnya. Isolat SP.1.3 menunjukkan karakteristik bakteri
Gram positif, katalase positif, oksidase negatif, glukosa positif, fermentatif dan motil. Isolat SP.1.3 diduga sebagai bakteri Bacillus sp. Menurut Barrow and Feltham (1993), Bacillus sp sebagian besar Gram positif (kecuali B. anthracis dan B. mycoides) berbentuk batang, motil, Aerob (beberapa spesies fakultatif anaerob), tahan asam, katalase positif, oksidase tidak tetap, (terdapat beberapa bentuk non-motil), fermentatif, dan berbeda spesies berbedabeda dalam fementasi gula-gula.

Isolat SP.5.1 menunjukkan karakteristik bakter Gram negatif, katalase positif, oksidase negatif, non motil, dan tidak fermentasi gula-gula. Isolat SP.5.1 diduga sebagai bakteri Acinetobacter sp. Menurut Barrow and Feltham (1993), Acinetobacter sp merupakan bakteri Gram negatif, non motil, stric tly Aerob, ka tala se positif, oksidase negatif, dan degradasi gula-gula secara oksida tif a tau tidak sama sekali.

Isolat SP.5.2 menunjukkan ka rakteristik bakteri Gram negatif berbentuk batang, katalase positif, oksidase positif, motil, dan tidak fermentasi gula-gula. Isolat SP.5.2 diduga sebagai bakteri Pseudomonas sp. Menurut Barrow and Feltham (1993), Pseudomonas sp menupakan bakteri Gram negatif berbentuk batang, motil, Aerob, katalase positif, oksidase positif, dan degradasi gula-gula secara oksidatif.

Hubungan antar bakteri korsorsium dalam keadaan substrat yang mencukupi tidak akan saling mengganggu, tetapi saling bersinergi sehingga menghasilkan efisiensi perombakan yang lebih tinggi

Tabel 3. Hasil Penga matan Uji Antagonis

\begin{tabular}{|c|c|c|c|c|c|}
\hline Kode Isolat & SP.1.3 & SP.2.3 & SP.3.1 & SP.5.1 & SP.5.2 \\
\hline SP.1.3 & $x$ & - & - & - & - \\
\hline SP.2.3 & - & $x$ & - & - & - \\
\hline SP.3.1 & - & + & $x$ & - & - \\
\hline SP.5.1 & - & - & - & $x$ & - \\
\hline SP.5.2 & - & - & - & - & $x$ \\
\hline
\end{tabular}


Tábel 4. Id entifika si Ba kteri Isolat Terba ik Seca ra Fenotip ik (Uji Biokimia)

\begin{tabular}{|c|c|c|c|c|}
\hline \multirow{2}{*}{ No. } & \multirow{2}{*}{ Uji Biokimia } & \multicolumn{3}{|c|}{ Kode Isolat Ba kteri } \\
\hline & & SP.1.3 & SP.5.1 & SP.5.2 \\
\hline 1 & $\mathrm{KOH} 3 \%$ & + & - & - \\
\hline 2 & Katalase & + & + & + \\
\hline 3 & O ksid a se & - & - & + \\
\hline 4 & TSIA & $\mathrm{K} / \mathrm{A}, \mathrm{H}_{2} \mathrm{~S}-, \mathrm{G}-$ & $\mathrm{K} / \mathrm{K}, \mathrm{H}_{2} \mathrm{~S}-, \mathrm{G}-$ & $\mathrm{K} / \mathrm{K}, \mathrm{H}_{2} \mathrm{~S}-, \mathrm{G}-$ \\
\hline 5 & பА & - & + & + \\
\hline 6 & $\mathrm{O} / \mathrm{F}$ & $\mathrm{F}$ & - & $\mathrm{O}$ \\
\hline 7 & Indol & - & - & - \\
\hline 8 & Omithin & - & + & + \\
\hline 9 & Esculin & - & + & - \\
\hline 10 & Citrat & - & - & + \\
\hline 11 & Urea & + & - & + \\
\hline 12 & Gelatin & - & - & - \\
\hline 13 & MR & - & - & - \\
\hline 14 & VP & - & - & - \\
\hline 15 & $\begin{array}{l}\text { Motility (semi } \\
\text { solid) }\end{array}$ & Motil & Non Motil & Motil \\
\hline 16 & Glukosa & + & - & - \\
\hline 17 & Sukrosa & - & - & - \\
\hline 18 & Maltosa & - & - & - \\
\hline 19 & La ktosa & - & - & - \\
\hline 20 & Identifikasi & Ba cillus sp & Acinetobacter sp & Pseudomonassp \\
\hline
\end{tabular}

selama proses pengolahan. Interaksi sinergisme antara konsorsium bakteri yang digunakan atau interaksinya dengan lingkungan menyebabkan terjadinya proses degradasi bahan cemaran organik di dalam limbah (Saha and Santra, 2014). Persiapan konsorsium bakteri dalam akuakultur memiliki peran antagonis terhadap patogen (biokontrol dan probiotik) atau meningkatakan kualitas a ir (bioremediasi) yang tergantung pada perannya di lingkungan (Panigrahi and Azad, 2007).

\section{KESIMPULAN}

Berdasarkan hasil pengukuran zona hidrolitik, zona antibakteri, dan sifat antagonis yang dihasilkan dapat diseleksi kandidat bakteri probiotik yang dapat dikembangkan sebagai konsorsium probiotik untuk membersihkan tambak udang dari bahan organik. Pada penelitian ini telah dapat diseleksi 3 isolat bakteri terbaik yang mempunyai potensi untuk dikembangkan sebagai agensia bioremediasi tambak udang, karena mempunyai kemampuan untuk menghasilkan enzim proteolitik, amilolitik, selulolitik, lipolitik, dan a ntibakteri.

\section{UCAPAN TERIMA KASIH}

Penulis menyampaikan terima kasih kepada dewan redaksi Jumal Kelautan Tropis yang telah memberikan pengarahan dalam pembuatan jumal ilmiah ini serta semua pihak yang telah memberikan 
dukungan dan bantuan kepada penulis selama penelitian dan penyusunan penulisa $n$.

\section{DAFTAR PUSTAKA}

Anand, P. T., Bhat A. W., Shoushe Y. S., Roy U., Siddharth J., and Sama S. P. 2006. Antimicrobial activity of manine bacteria associated with sponges from the waters off the coast of South East India. Mic robiol. Res., 161: 252-262

Anthony, S. P. and Philip R. 2006. Bioremediation in Shrimp Culture Systems Bioremediation in Shrimp Culture Systems. NAGA, World Fish Cen. Quart. 29: 3-4.

Avnimelech, $Y$ and G. Ritvo. 2003. Shrimp And Fish Pond Soils: Processes And Management. J. Aqua., 220: 549-567.

Badjoen, M. dan T. Widiyanto. 2008. Penggunaan Bakteri Nitrifikasi untuk Bioremediasi dan Pengaruhnya Terhadap Konsentrasi Amonia dan Nitrit di Tambak Udang. Jumal Oseanologi dan Limnologi., 34(2): 261278.

Barrow, G. I. and Feltham R. K. A. 1993. Cowan and Steel's Manual for Identification of Medical Bacteria $3^{\text {rd }}$ Edition. Cambridge University Press, 331p.

Cappucino, J. G. and Sheman Natalie. 1999. Microbiology: A Laboratory Manual - 5th Ed. Benjamin/Cummings Sc ience Publishing, Califomia, 477p.

Feby, A. and Nair S. 2010. Spongeassociated bacteria of Lakshadweep coral reefs, India: resource for extracellular hydrolytic enzymes. Adv. Biosci. Biotechnol. 1: 330-337.

Felix, F., Nugroho T. T., Silalahi S., dan Yuslina O. 2011. Skrining Bakteri Vibrio sp Asli Indonesia Sebagai Penyebab Penyakit Udang Berbasis Teknik 16S Ribosomal DNA. Jumal Ilmu dan Teknologi Kela utan Tropis, 3(2): 85-99.

Gamo, Y. S. 2004. Pengembangan Budidaya Udang dan Potensi Pencemarannya Pada Perairan Pesisir. Jumal Teknik Lingkungan P3TL-BPPT, 5(3): 187-192.

Juneius, C. E. R. and Selvin J. 2012. Identification, phylogenetic charac- temization and preliminary screening of primary and secondary metabolites producing bacteria associated with marine sponge Axinella donani. Indian J . Drugs Dis., 1(1): 20-26.

Kasana, R. C., Salwan R., Dhar H., Dutt S., and Gulati A. 2008. A Rapid and Easy Method for the Detection of Microbial Cellula ses on Agar Plates Using Gram's lodine. Curr. Microbiol. 57: 503-507.

Kila wati, Y. dan Ma imunah Y. 2014. Kualitas Lingkungan Tambak Intensif Litapenaeus vannamei Dalam Kaitannya Dengan Prevalensi Penyakit White Spot Syndrome Virus. Res. Jour. Lif. Sci., 1(2): 34-41.

Maulina, I., Handaka A. A., dan Riyantini I. 2012. Analisis Prospek Budidaya Tambak Udang di Kabupaten Garut. J umal Akuatika, 3(1): 49-62.

Panigrahi, A. and Azad I. S. 2007. Microbial intervention for better fish health in aquaculture: the Indian scenario. Fish Physiol. Biochem., 33:429-440.

Radjasa, O. K., T. Martens, H. P. Grossart, T. Brinkoff., A. Sabdono and M. Simon. 2007. Antagonistic Activity of a Marine Bacterium Pseudoalteromonas luteoviolacea TAB4.2 Associated with Coral Acropora sp. J. Biol. Sci., 7(2): 239-246.

Saha, A. and Santra S. C. 2014. Isolation and Characterization of Bacteria Isolated from Munic ipal Solid Waste for Production of Industrial Enzymes and Waste Degradation. J. Microbiol. Exp., 1(1): 003.

Setyati, W. A. dan Subagiyo. 2012. Isolasi dan Seleksi Bakteri Penghasil Enzim Ekstraseluler (Proteolitik, Amilolitik, Lipolitik, dan Selulolitik) yang berasal dari Sedimen Kawasan Mangrove. J uma I Ilmu Kelautan., 17(3): 164-168.

Santos, G. 2014. Probiotics An Essentials Tool in Intensive Shrimp Aquaculture. $5 \mathrm{~m}$ Publishing, Benchmark House, England.

Sha nmugha priya, S., J. Krishna veni, J oseph S., R. Gandhimathi, M. Arunkumar, T. Thangavelu, G. S. Kiran, K. Natarajaseenivasan. Optimization of extracellular themotolerant alkaline protease produced by marine 
Roseobacter sp. (MMD040). Biopro. Biosyst. Eng., 31:427-433.

Zhang, C., and Kim S. 2008. Research and Application of Marine Microbial Enzymes: Status and Prospects. Mar. Drugs., 8(6): 1920-1934.
Zulaikhah, S.T. 2005. Analisis Faktor-Faktor yang Berhubungan dengan Pencemaran Mikroba pada Jamu Gendong di Kota Semarang. Program Pasc a sa rjana Undip, Semarang. 